ESJ Humanities

\title{
Migration -Trafficking nexus in Post-Soviet Tajikistan
}

\author{
Sanchita Chatterjee \\ $\mathrm{PhD}$ Research Scholar, Centre for Inner Asian Studies (CIAS) \\ School of International Studies (SIS), Jawaharlal Nehru University \\ New Delhi, India
}

Doi:10.19044/esj.2021.v17n20p84

Submitted: 04 January 2021

Accepted: 22 June 2021

Published: 30 June 2021
Copyright 2021 Author(s)

Under Creative Commons BY-NC-ND

4.0 OPEN ACCESS

Cite As:

Chatterjee S. (2021). Migration -Trafficking nexus in Post-Soviet Tajikistan. European Scientific Journal, ESJ, 17(20), 84. https://doi.org/10.19044/esj.2021.v17n20p84

\section{Abstract}

Human trafficking, for the manipulation of migrant labour, is a violation of human rights. The spike in human trafficking is partly due to the rapid expansion of labour migration in the neoliberal period. The former Soviet zone has become one of the world's major human migration sections in the last decade. The article analyses the case of migration and trafficking in Tajikistan as remittances amounted to nearly half of the country's gross domestic product. In Tajikistan, lack of economic prospects, increasing poverty level, presence of blurred boundaries, leads to the cycle of illicit migration flows which resulted in human trafficking. Human trafficking is a multidimensional issue exacerbated in the countries of destination by poverty and gaps in economic openings versus unmet labour hassles and stern migration commandments. The migration of the Tajik people shortly began after the independence of the country and largely to support subsistence to the families leaving behind. Majority of these migrants prefer Russian federation as their main destination to work where corruption and human trafficking problem is huge. There are limited governing bodies to regulate recruiters' activities, so migrant workers are at the mercy of recruiters who are known to charge exorbitant fees that indebted migrant worker before arriving in their destination countries. Labour trafficking is a global humanitarian issue but there is scarcely any quantitative research on the issue. This study examined labour abuse indicators among migrant Tajik workers in the Russian Federation and the subsequent human trafficking risks with fresh 
vulnerabilities created by the economic crises and the covid-19 pandemic in 2020 .

Keywords: Labour Migration, Human Trafficking, Russian Federation, Forced Labour, Tajik migrant workers

\section{Introduction}

Trafficking, smuggling and migration are distinct issues but they are interrelated. Migration might actually occur via normal or irregular network. It can also be triggered by war, an economic crisis, or an environmental catastrophe. Majority of the illegal or irregular migration is assisted by the middlemen or smuggler who facilitates the process for an emolument. Sometimes they claim an excessive emolument and may well uncover the migrant to grave perils in the path of their trip. But in the case of smuggling, a migrant person is normally free after they arrive at their particular destination and may not encounter the smuggler again. Trafficking is not the same as it encompasses the movement of people to exploit their labour or services. Researchers suggest that a vast number of migrant workers are trafficked for several purposes. Many people are acquainted with well-paid work overseas either through "recruitment agencies" or by people eager to find them a job and coordinate their trips. With most trafficking victims, their major issues can only start when they settle in the destination country, as they have not been offered employment but instead are obliged to work at a job or in circumstances with which they do not conform. It is no accident that the increase in trafficking occurred in the course of a time of increasing international demand for migrant workers, which was not sufficiently understood or encouraged. Dearth of regular migration channels left the migrants to rely on the irregular means to obtain jobs outside the country to improve sustainable livelihood. Given this, many policymakers have responded to the issue by introducing tighter immigration laws, which usually make smuggling and trafficking more lucrative and make matters worse.

This article, therefore, seeks to look at the issue of migration and trafficking within a broader migration framework and analyse the impact on the Central Asian countries particularly Tajikistan. Tajikistan is a small, mountainous Central Asian Republic. It became an essential part of the Soviet command economy after the Bolshevik Revolution in October 1917 (Mughal 2007). Independence in Tajikistan was a "spectacular failure" following the Soviet implosion, as the country shifted from a highly structured command system to an economic capitalism (Mughal, 2007). The civil war (1992-1997) followed by the independence undermined the country's political and economic system. Several challenges like weak infrastructure, local governance, unemployment, corruption and the mass migration of ethnic 
Russians and other professionals shadowed after the civil war. Tajikistan soon became the second-largest labour sending country in the region after the civil war. One in four families has at least one member of their family working outside. Total labour migration from Tajikistan is expected to range from 500,000 to 800,000 people, representing around 10 per cent of the 6.9 million total populations (ILO, 2010). Migration is both risky and uncertain for all migrants and non-migrants living in the country. Irregular migration has given rise to new forms of trafficking in the Central Asian region. Human trafficking is, according to UNODC (2008), a mechanism in which people are kidnapped and recruited, transported and abused in the countries of destination, or even in the countries of origin. The notion of human trafficking is strongly connected with that of forced labour where people are held by improper means such as force, fraud or deception, to exploit them.

'When a victim of forced labour is recruited, transported or harbored by offensive means, he or she may be legally defined as a victim of trafficking and the recruiter, transporter or harbor is a trafficker'(Sarrica, 2015). The Central Asian republics are facing labour migration but not to the degree that Tajikistan faces. With extensive illegal migration of labour, trafficking in human beings is evident in all its forms which have serious implications for the region. If a migrant worker is forced to work they become victims of trafficking in human beings as they work under restrictive and unfavourable conditions (OSCE, 2011).

\section{Data and Methods}

Despite the intensity of trafficking worldwide, there is very little data available. The article is based on theoretical framework to analyse the intensity of trafficking among the labour migrants in Tajikistan. A bibliometric analysis is adapted with qualitative approach. Primary sources of data collected from the Trafficking in Persons Report, State statistical Committee of Tajikistan, World Bank, and International Organization for Migration reports were also analysed and adapted as a base for the research. The aim of this research was to evaluate human trafficking research activity and trends among the labour migrants in Tajikistan.

The hidden and unseen nature of the trafficking victims and offenders has made human trafficking a challenging topic to study. This makes typical sampling methods difficult for researchers to conduct. In Central Asia it is particularly difficult to identify, as a result, much of the research has depended on yearly 'Trafficking in persons Reports', data from UNODC, IOM, ILO etc and individual government databases, resulting in recommendations that aren't based on first-hand accounts. The article is done based on a qualitative research methodology by studying and identifying gaps in research materials from these organizations and also focus on the quantitative data obtained from 
the government databases. The study tries to picturize the intensity of the Human Trafficking among the migrants working in the destination countries by studying all the quantitative and qualitative data available.

\section{Profile of Tajik Migrant Worker}

Tajikistan is a small, mountainous Central Asian nation. It is the region's second-biggest labour-sending country after Uzbekistan in the Central Asian region. One in four families has at least one member of their family working outside the country. Political and economic instability, civil war and a surplus of labour resources have triggered the country's migration flows. Tajik migrants contribute tremendously to the economies of host and countries of origin. In Tajik history, migration isn't a new phenomenon. In the recent past, a large percentage of the country was actively involved in labour migration when Tajikistan was part of the former USSR. Given the minimal job opportunities at home, external migration is the population's primary means of subsistence. Labour migration increased in 1994 and 1995 as a result of the difficulties caused by the country's civil war and the collapse of previous employment areas during the transition to a market economy (Olimova and bosc, 2003). In Tajikistan less than 7 per cent of the land is arable (Tajikistan Extended Migration Profile, 2010). Tajikistan has recently undergone shifts in its demographic profile. With its increasing population growth and shortage of job, migration proved to be a saviour for the majority of the population. According to World Bank statistics, Tajikistan's population growth is highest among other Central Asian countries at an average of over 2 per cent per year. With its growing workforce and devastating economy, Tajikistan is ineffective in producing enough labour markets for the people. Past studies have found that Tajikistan's labour migrants are predominantly men, and mostly rural. Given that the majority of the population lives in rural areas, the problem in rural areas is serious than in urban areas. World Bank data indicates that in $2009,47.2$ per cent of the total population lived below the poverty line.

The age profile of migrants is dominated by young persons (ILO, 2010). Most of the migrants now comprise a young age population (15-29 years) that exceeds 53 per cent of the total migrants working outside the country. The financing for the trip to work in foreign countries is generally directed from the family $(59.4 \%)$, themselves (16.3\%), friends (13.7\%), banks, neighbours (3.4\%) (IOM, 2009). The rise in the oil industry in Russia attracted labourers from neighbouring post-Soviet states to work in the country. The post-Soviet countries enjoy a visa-free regime for themselves, making it easier to engage Tajikistan's labour migrants. For a similar job available in Tajikistan, salaries in Russia are far higher.

Tajik labour migrants' level of education is very poor. While 73 per cent of labour migrants have secondary education, 10 per cent and 8.2 per cent 
have only intermediate and/or higher levels of technical education, respectively (Tajikistan Extended Migration Profile, 2010). Labour migrants' educational level varies according to the geographic area where they come from. Those coming from a rural area are less than urban regions. Tajikistan's labour migration is estimated at 800,000 or 11 per cent of the total population, though the figure could be higher due to fractional documentation and statistics.

Tajik economy is heavily dependent on migrant remittances, which according to the World Bank accounted for 43.76 per cent of GDP in 2013. That makes Tajikistan the top remittance-receiving country in the world as a share of GDP. In Tajikistan the disparity between high rates of population growth with less economic opportunities, migration proved an effective way to earn livelihood in Russia which offers higher salary to these immigrant labourers (Mohapatra, 2013). Remittances help households diversify their source of income, reducing their vulnerability to adverse poverty (Mughal, 2007). Remittances significantly helped in the poverty reduction of the country where poverty percentage fell from 96 percent in 1999 to 47 percent in 2009 and an estimated 36 percent in 2013 (World Bank, 2015).

Table I: Migration of population in Tajikistan (2005-2018)

\begin{tabular}{|c|c|c|}
\hline Year & Total Migrants (in persons) & GDP per capita (USD) \\
\hline 2005 & 27311 & 340.58 \\
\hline 2006 & 30554 & 408.84 \\
\hline 2007 & 38761 & 526.64 \\
\hline 2008 & 37651 & 715.87 \\
\hline 2009 & 37231 & 676.12 \\
\hline 2010 & 36134 & 749.55 \\
\hline 2011 & 38867 & 847.38 \\
\hline 2012 & 38917 & 969.30 \\
\hline 2013 & 40304 & 1048.23 \\
\hline 2014 & 45344 & 1104.17 \\
\hline 2015 & 40135 & 929.10 \\
\hline 2016 & 37606 & 802.52 \\
\hline 2017 & 41150 & 806.04 \\
\hline 2018 & 45046 & 826.62 \\
\hline
\end{tabular}

Source: State Statistical Committee of Tajikistan (Total Migrants), World Bank (GDP per capita USD)

From Table I, it is evident that labour migration in Tajikistan is a means of improving living standard in Tajikistan. An increase in emigration along with an increase in GDP per capita forms a direct correlation with the country's overall economic performance. The above data consisted only of labour migrants working legally in the countries of destination. 
Strong push factors are present in Tajikistan. Tajikistan has the lowest per capita wage and GDP among the CIS countries. There are two main types of Tajik migrants working abroad: permanent abroad migrants (permanent migrants) and seasonal, temporary migrants (they work from spring to autumn and return for winter in Tajikistan). The number of illegal migrants is quite high in size. About 95 per cent of migrants choose to serve as their preferred destination in the Russian Federation. Increased illegal migration has provided soft targets for the networks involved in trafficking. Such illegal migrants often create a parallel shadow economy in the destination countries. These migrants are kidnapped, threatened and exploited by the police, border guards and middlemen who have made them pay large bribes for continuing their work or reaching the countries of destination. They are also denied basic living services, medical facilities and are subject to extended working hours without proper documentation (Umarov and Warikoo, 2015).

\section{Destination countries for the Tajik Labour Migrants}

Labour migration in Tajikistan is a typical trend to focus on the Russian Federation and other CIS countries. More than 95 per cent of migrants from Tajiks prefer to go to Russia. Moscow, Yakutsk (15 percent), Saint Petersburg (around 6 percent), Yekaterinburg (around 6 percent) and Tyumen (around 2-3 percent) are the main flow (around 60 percent). Other cities have limited migrant-flow shares. Migrant earnings differ insignificantly in different cities (IOM, 2009). At the time of the civil war, however, many feared that they would be engaged in the war and they migrated mainly to the Russian Federation, Ukraine, Belarus and Kazakhstan (Umarov and Warikoo, 2015).

International organizations estimate that the number of Tajik citizens living and working in Russia is close to one million. As per a visa-free regime in the Russian Federation, Tajik labour migrant legally enters Russia, but according to the Russian authorities' statistics, an enormous level of illegal and irregular migration is observed. In 2010, 268,000 labour migrants from Tajikistan went to the Russian Federation as legal migrants but the Russian government reported that 650,000 persons illegally entered from Tajikistan on the same year (Vinokurov and Pereboye 2013). There may be more than a million illegal migrants across Russia, according to various unofficial statistics.

According to US Department of State, Trafficking in Persons(TIP) Report 2019, Russian Federation, UAE, Kazakhstan, Saudi Arabia (to a lesser extent), and other neighbouring Central Asian countries, Turkey and Afghanistan, are the major destination countries for the victims of Tajik trafficked victims. According to the UN / IOM report (2005), most of these migrants are illegal and more than 75 per cent of illegal migrants are paying 
cash under the table to begin the migration process which paved the way for workplace harassment (IOM, 2009). At least two-thirds of migrant employment occurs in Russia's informal economy, which increases the vulnerability and a highly lucrative market for traffickers, intermediaries, and employers (Tyuryukanova, 2005). IOM (2014), report that Tajikistan's maximum labour migrants are identified as irregular or undocumented because they breach the Russian registration system. The reasons for irregular status are the low level of education of the migrants who are unable to understand the different registration process while entering Russia. In Russia, the registration system is quite complicated and complex. Migrants from a visa-free regime entering Russia had to be registered within three days of entry otherwise deemed illegal, which in turn creates a huge mess for undereducated migrants who are unable to acquire the required documentation in that required time. To complete the registration process in the stipulated time, some go through intermediaries to get paperwork by paying a lot of money. It often led to falsified documents that later pose a major problem for migrants (Chiovenda, 2013). The Russian government has changed the registration law which now requires the migrants to receive work permits from the employer but sometimes the employers harass the migrants in receiving the work permits. They also faced serious difficulties in the country without the relevant documents.

\section{Labour Trafficking from Tajikistan}

Although there have been many international concepts of trafficking in human beings, it was the Trafficking Protocol that introduced the broad term of the crime under international law. Article 3 of the Palermo Protocol (2000) on Trafficking states that

"'Trafficking in persons' shall mean the recruitment, transportation, transfer, harbouring, or receipt of persons, using threat or use of force or other forms of coercion, of abduction, of fraud, of deception, of the abuse of power or a position of vulnerability or the giving or receiving of payments or benefits to achieve the consent of a person having control over another person, for exploitation. Exploitation shall include, at the minimum, the exploitation of the prostitution of others or other forms of sexual exploitation, forced labour or services, slavery or practices similar to slavery, servitude or removal of organs" (UNTC, 2000)

Forced labour and trafficking for sexual exploitation are known worldwide, with trafficking sometimes referred to as a modern type of slavery. Under oppressive working conditions, the words ' forced ' and ' slave ' labour evoke images of bound labourers tied to an owner. New forms of withholding 
wages and proofs of identity, restriction of workplace freedom may all come under the realm of forced labour in modern times.

All forced labour cannot be a consequence of trafficking. Conversely, almost all cases of human trafficking end in forced labour (except trafficking for removal of organs). Lack of viable options can force a person to a substandard working condition which cannot be termed as forced labour according to Palermo protocol. If the recruiter purposely takes advantage of the lack of an alternative to exploit the worker it falls under the category of forced labour. Therefore trafficking for forced labour should assess the situation of external constraints that impact the free consent of the workers amounting to trafficking (ILO, 2008). More than 21 million people worldwide are victims of trafficking for forced labour, of which around 1.6 million people are from the post-Soviet area (ILO, 2012).

The Migration Research Centre estimates that 1 million people are subjected to exploitive labour conditions in Russia with withholding the documents and pay, physical abuse and poor living conditions (TIP report, 2012). There are several case studies conducted by different organizations like Organization for Security and Co-operation in Europe (OSCE), Human Rights Watch, and International Organization for Migration (IOM) which expose the nature of labour exploitation suffered by the migrants of Tajikistan (Stephanie, et.al, 2013) For example, in 2008, Migrant workers were recruited through television advertisements to an employment agency named Vostok farm. The workers sign agreements to work in construction but upon reaching there, their passports were withheld and they are forced to dig stones in quarries with hand tools. Those who refused to do the work were told that they will deport them. The victims forcefully worked there for 85 days without pay and forced to live in an abandoned refrigerator truck and two cargo containers with dirty mats and cots and were denied food if they rejected to work (Stephanie, et.al, 2013; Dutta, 2016). Another report of trafficked Tajik doctors (both male and female) to Yemen for forced labour at different clinics for substandard wages is also observed where also, female doctors were forced to engage in prostitution.

According to the reports of Tajik NGO, Modar "most trafficking victims are young women, usually with no higher education and no job prospects, making it easier for traffickers to attract them with false promises of legitimate and well-paying jobs abroad, and then sell the women to brothels"( Regional Central Asia conference, 2006). In 2013, the governmentassisted 17 human trafficking victims, while NGOs assisted 67 more (48 victims of forced labour and 19 victims of trafficking for sexual exploitation). These labour migrants' faces serious consequences for men who suffer exploitation and abuse for years lacking proper health care, mistreatment by police and employers (TIP REPORT, 2014). 


\section{Trafficking or Smuggling? Where Tajikistan fits?}

The trafficking/smuggling of binaries set up by the two Palermo Protocols offers far less protection to the second category of persons. While trafficked persons are considered innocent victims, smuggled persons are considered criminals. Both trafficked and smuggled people most often choose to leave their homes, whether as economic migrants, asylum seekers or reunite with their families or for other reasons (Aronowitz, 2001). Irregular migration raises very real dilemmas for Central Asian nations and also exposes migrants to instability and vulnerability. Smuggled people may become stuck in exploitative working conditions due to forms of debt bondage to those who have arranged their passage, to take only one example from the many available. In the overlap between smuggling and trafficking, we find a continuum of control that spans confiscation documentation and psychological control (through reference to "honour," threats of violence against family members, and so on), all the way to forced confinement and violence on the other (Aronowitz, 2001). Many people may begin their journey in one category and end in another one which establishes an operational connection between trafficking and smuggling that is not recognized by the international Protocols (Gallagher, 2001). Persons who are trafficked and smuggled lie along a continuum of violence that the relevant legal instruments largely ignore. Closing borders may completely halt trafficking and smuggling, but in today's interconnected world this is, of course, increasingly difficult. Tighter border controls have contributed to the expansion of smuggling and trafficking networks.

According to an article on trafficking in Asia by Ronald Skeldon (2000), Human smugglers networks have proven to be extremely successful in illegally transporting large numbers of people and in amassing considerable income. Violence, and manipulation are an integral part of smuggling and learning about smuggling without trafficking are virtually impossible. Similarly, in the case of Tajikistan, unemployment increased as the property was privatized, and jobs usually available at Soviet collective farms were gone after independence. Wages were erratic for teachers, physicians and others and many schools and hospitals were forced to close. Particularly those institutions that remain open face persistent workforce shortages. Those conditions pushed the people to migrate to the neighbouring states in search of work prospects and employment. Majority of the people are desperate to get a job outside the country legally or illegally. The lack of legal security and insufficient information on the part of the employees in this job sector makes them extremely vulnerable to exploitation and violence from different sources. The weak border protection that followed the Soviet Union's demise opened the region to human smuggling networks of criminals and refugees from as far as South Asia and Africa on their way to Western Europe (IOM, 2003), this topic 
presents a particular challenge for the region's law enforcement authorities, as migrant smuggling often requires false passports and/or visas.

As legal labour migration channels are limited, illegal migration is likely to take precedence. The implications of this migration for the countries concerned, as well as for the labour migrants themselves, are significant. Because of their irregular situation, most labour migrants do not enjoy the same rights of protection as other ordinary citizens and are thus more vulnerable to underground employers ' exploitation. Human trafficking is the most egregious type of illegal migration. The most onerous form of migration across the region is human trafficking for labour exploitation, which is becoming a salient feature of migration dynamics in Tajikistan. The business of trafficking maintains a low profile, where victims are forced to remain quiet by the traffickers and there are no official figures available. Labour migration is seen as a boon to the poor Tajiks to maintain their livelihood, so the majority of them wish to work abroad to earn money even if they know of taking the illegal channels of migration. Sometimes these migrants willingly wished to be smuggled and end up as a trafficked victim abroad.

\section{Violation of Rights and Discrimination of Labour Migrants in Russia}

Labour migration has become an important part of the world economy; bringing migrants to developed countries where demand for cheap labour is extensive. Throughout recent decades, migration and related violations have become significant public and political issues. However, these issues remain under-researched throughout Russia even though the country is a primary destination for migrants from surrounding countries. Russia became the national focal point for repatriation and labour migration, primarily from the former Soviet Union, after the breakup of the U.S.S.R. According to the World Bank (2016), Russia is currently ranked fifth in the world in terms of labour migration scale (approximately 9-10 million people) and about 2 million people have irregular status according to Ministry of the Interior (MVD) (RIA, 2018).

Russian Federal Migration Service Director K. O. Romodanovsky has noted that migrant labour accounts for 8\% of Russia's GDP (Ryazantsev, 2014). The existing mobility control system, including remnants of Soviet systems such as propiska ${ }^{1}$, has put many international migrants at risk for trafficking, particularly irregular migrants. Russia's migration policies often make the shadow economy more attractive for both employers and employees by reducing the costs and time associated with endless bureaucratic procedures and regulations. In the informal economy, at least two-thirds of migrant work

\footnotetext{
${ }^{1}$ Stalin, introduced Propiska for the control of the Soviet population and limited the possibility for citizens of the USSR to choose their place of residence. It asked every person to have a fixed place of residence approved by authorities.
} 
exists in Russia. As a result, migrant workers are a highly profitable market for traffickers, intermediaries, employers and others who seek to exploit their vulnerability (Tyuryukanova, 2005). Another factor contributing to trafficking is the country's vastness: Russia comprises 11 time zones. Trafficked victims are usually isolated from their friends or family and the likelihood of a migrant returning to 'natural' life in remote areas or national republics with unknown languages and distrust toward outsiders is low (Buckley, 2018).

According to IOM (2009), the total number of legitimately listed labour migrants is 429,995 . But other international organization expected the number to as many as 800,000 to 1 million during 2008. These migrants are considered as illegal migrant workers in Russia. They are also not recorded and are unable to use benefits given to a legal migrant. These migrants are subject to hard labour, poor working conditions, limited medical facilities, long working hours, and other harsh measures which are included in the UN convention for labour trafficking. The origin of trafficking occurs even on the entry of the migrants to the destination countries where corruption is a severe problem in the post-Soviet states and Russian federation itself (Kelly, 2005). Tajikistan has been placed under 'Tier 2' group in 2019 which states that it is vulnerable and the government policies do not comply with the according to the UN anti Trafficking protocol (TIP Report, 2019). Tajikistan is identified primarily as a source country where men, women and children are subjected to forced labour, and sex trafficking. In Tajikistan, export and trafficking of forced labour exceed trafficking for sexual exploitation (IOM, 2006). As the majority of the migrants work in the informal economy in the destination countries, there is very lack of legal protection which makes them vulnerable to the trafficking network (Olimova and bosc, 2003). The intensity of labour migration is growing day by day as there are severe unemployment and poverty in the country.

With the link of these unregulated migrants, more than 70 percent in Russia are prone to various forms of trafficking which includes restriction of freedom of movement, or confiscation of documents by the employers. Migrants found jobs with the help of informal networks or through friends, family and relatives who have come before them and are regarded as secondclass workers in Russia (UNICEF, 2011).

According to the findings of the regional Central Asia conference (2006), the exact figure of trafficking annually from Tajikistan is unknown but the major factors leading to human trafficking in Tajikistan are the economic vulnerability, extreme poverty, high unemployment. Trafficking of men is closely associated with labour migration, while the trafficking of women is often for sexual and labour exploitation. One study of trafficking shows that "almost all male victims were married, but most female victims were unmarried or divorced"(ADB, 2016). The language skills of the migrants help 
them to secure jobs outside, but the young generation labour migrants have minimum language skill which possesses a threat of exploitation in the host countries. For the vast bulk of the population, the Russian labour market is more interesting than the jobs available in Tajikistan which demands higher education (Mughal, 2007). Corruption is an important factor which increases the risks of vulnerability. All the Central Asian States are found toward the bottom of the Corruption Percentage Index of the Transparency International Corruption Percentage Index. With four out of five of these countries ranked in the bottom 30 countries, those with the highest level of perceived corruption (Regional Central Asia conference, 2006). ILO (2006) reports that illegal migrants work in the informal economy of Russia which is highly profitable for traffickers, intermediaries, and employers.

One form of exploitation of a person is slave labour, in which the exploited person carries out work while in a state of slavery or subject to customs or similar social institutions. Typical features of such work include the lack of worker freedom and arbitrariness in the conduct of the employer (Zagorsky, Kaufman, Moiseeva, and Radutnaya, 2009). The forced nature of labour may take the form of modifications to the conditions of an employment contract involving the unjustified extension of the worker's responsibilities, types of jobs, hours worked, reduction in pay and time off, unjustified sanctions, and so on (Gromov, 2006).

Amid economic transformation and social change in the Russian Federation in the 1990s and 2000s, trafficking in human beings and slave labour became quite widespread. As migration intensifies, in recent years, crimes related to the organization of illegal migration in Russia have become common. Despite the magnitude of the issue, there have been no complete and detailed statistics about this issue for a long time. The modern Russian economy can be characterized as "migrant-dependent" as every year between 1,5 million and 2 million official labour migrants arrive in the country (Ryazantsev, 2014). Within migration flows from the migrant workers' countries of origin new socio-demographic population groups have emerged. In Central Asian countries, for example, people living in rural districts, small towns, women and young people have started to engage more actively in migration (Ryazantsev and Horie, 2012). Rough expert estimates put the number of migrant workers in slavery at around 600,000, or 20 per cent of all migrant workers in Russia. The president of the Association of Russian Human Rights Lawyers, E. Arkhipov, estimates the value of a native of one of the Central Asian states on the criminal market between US\$ 300 and US\$ 500, and says, "Labour migrants can be ordered through criminal networks and also through migrant workers leaders." (Ryazantsev, 2014). Migrants generally become slaves because of debts: they have to pay criminals just to get to Russia and return home (Rex news, 2012). 


\section{Economic sectors of the Migrants in the Russian Federation}

In the Russian Federation, the "migrant" sectors of the economy can be identified, in which employers actively exploit the labour of foreign workers. The main sectors are construction and repair works. An alarming finding in Tajikistan from a survey by IOM, (2014) states that more than 80 per cent of migrant workers had only informal contracts, that is, oral contracts with their employer. Without any formal written contract, these migrants are regularly abused which is considered as a widespread problem among foreign workers in the Russian Federation (Human Rights Watch, 2009). Sending home money is part and parcel of labour migration, more so for Tajik migrant workers, who often work seasonally in the Russian Federation and send as much as possible of their wages to their families. Their salaries allow them to accumulate capital that would otherwise not be available to them in Tajikistan and send large shares of their profits through either official or unofficial channels to their families.

Unlike other sectors in the construction sector, workers are being "transferred" by entire gangs after completing a building for a certain reward from one employer to another. Documents of the workers, often "retained" by the employer, can be transferred from the old master to the new one without even passing into the hands of the workers. Document confiscation is in itself a widespread method of exploiting and retaining control of the workers. Nearly one-third of workers in the construction sector do not hold passports. In this way, migrant workers are robbed of the freedom to freely choose their job and employer and become "confined" to their employer and cannot quit (Tyuryukanova, 2006). The regions of Moscow, the Moscow Oblast, Smolensk Oblast, Yaroslavl Oblast, Rostov Oblast, Samara Oblast and Krasnodar Krai have experienced a construction boom in Russia. Migrant workers mainly flock to these regions for working in these regions.

Apart from the construction sector, trade and catering is the second most attractive sector for the migrant workers. The exploitation of foreign workers' labour also occurs here on an extremely large scale. Research shows that debt bondage is the most widespread form of exploitation in this sector. Methods of placing a worker in a debt bondage situation are widely known among employers who own sales outlets and shops, and the "experiencesharing" practice is well established (Tyuryukanova, 2006).

The labour migrants also highly prefer another economic sector, the processing industry. Various forms of labour exploitation are widely used by this economic sector as work without an official contract, overtime, poor working and living conditions and non-paid wages. Central Russia, in the Urals and Siberia, is home to large manufacturing sites that exploit migrant labour (Ryazantsev, 2014). 
In the transport sector too, migrant labour is actively used. Migrants also work as drivers of marshrutkas [fixed-route shares taxis], city buses, trolleybuses, etc. in many regions of Russia. Throughout recent years, there have been several conflicts arising out of the jobs of foreign workers throughout Russia's transport sector. From 1 January 2010 onwards, the Moscow City Council banned migrants from serving as drivers of the marshrutka. The prohibition did not stop businesses from hiring migrant labour, however. Within this economic sector, such forms of exploitation as overtime, the system of imposing fines for non-compliance with plans and accidents, and debt bondage are widespread.

The housing and utility sectors are among the most corrupt sectors in Russia which employ migrant workers. Research shows that the majority of migrant workers are not registered by employers in this economic field as their salaries are half of what Russian nationals earn. Also, arrangements exist in Moscow and other large Russian cities whereby Russian nationals are entered on the payroll but the work is done by CIS citizens (Ryazantsev, 2014). Migrant staff do not earn their wages on time, work more than the prescribed number of hours and live in miserable conditions (in basements, lofts and shafts of rubbish).

Migrant workers working in households also face labour exploitation. (Ryazantsev, Gorshkova, Akramov, and Sh. Akramov, 2012). Amendments to the law "On the legal status of foreign citizens in the Russian Federation" which came into force on 1 July 2010 formed the legal basis for the legalization of migrant workers working for private persons. Foreigners employed by legal entities must purchase a special license. This license became the brand-new document enabling foreign nationals to work in the Federation of Russia. The household sector employs a large number of migrants as gardeners, caretakers, guards and manual workers, particularly during the summer months. The domestic service sector includes a wide range of working types that require special skills, training and qualifications. They also include drivers, nannies, sick-nurses, health-care staff, and governesses etc.

\section{Methods of Recruitment}

Despite the high prevalence of Tajik nationals' labour migration abroad, especially to the Russian Federation; there is no intergovernmental agreement between the two countries on organized employment recruitment of Tajik nationals to the Russian Federation. The current agreement between the Government of the Republic of Tajikistan and the Government of the Russian Federation on labour-related activities and the protection of the rights of Tajik nationals in the Russian Federation adopted on 16 October 2004 covers only persons legally residing in the territory of the country of 
destination and working based on a contract of labour or civil law service. In this respect, this Agreement does not cover migrant workers in irregular circumstances (undocumented migrant workers) and/or those who work without jobs or service contracts.

Statistical data on labour migration in Tajikistan are collected and recorded by the Government of the Republic of Tajikistan Resolution "On the registration and return of Tajik nationals' external labour migration abroad." Most migrant workers come to Russia alone with the guidance of relatives and friends or private individuals who do not necessarily have the required job license and are not responsible for the migrants. Research published in 2004 showed that only 3-5 per cent of labour migrants in Russia used the official channels to get information and jobs ten years ago. In other words, unofficial networks and informal linkages were dominant in the jobs of migrant workers (ILO, 2004).

Many companies offer their services to help migrants obtain work permits, temporary residency permits and medical tests (required to obtain a work permit). These firms often provide false documents which expose migrants to the risk of being detained and expelled during police checks. Some provide genuine documents which raise questions about the relations between these private firms and the Federal Migration Service of Russia (FMS). Companies like "Inostranets," "Zakonnoe pravo" and others openly advertise their services using symbols of government and official-sounding names in St. Petersburg's main streets (FIDH, 2011).

Businesses wishing to hire migrants must get permission from the FMS nearly a year in advance and request a specific "quota.". To avoid this system, companies have increasingly turned to intermediary services, which in turn contract with migrants, who are then sent to work for the starting company. This "outsourcing" practice makes it difficult to hold employers accountable for violations of migrant workers ' rights since the relationship between employer and employee is difficult to prove in a court of law. The dominance of informal employment networks provides a favourable climate for the participation of migrants in irregular migration and human trafficking. People have no guarantees that even their closest relative or acquaintance can hire them. Nevertheless, when seeking work in Russia, the majority of migrant workers continue to rely on these ways of getting employment. In some cases, former victims of human trafficking may become recruiters. The Russian Federation's mechanism for controlling labour migration is still extremely flawed, allowing unscrupulous employers and offenders to deliberately lure labour migrants into human trafficking and labour abuse. 


\section{Legislation of trafficking in the Russian Federation and Tajikistan}

Despite the pervasiveness of the problem of trafficking in human beings and irregular migration in the countries of the former USSR in the 1990s, these issues remained outside the field of view of the Russian Federation's state authorities for a long time. Russia is a country of origin, transit and destination for men, women and child trafficking. Estimated to range from 0.6 to 1.5 million victims are trafficked in Russian federation (TIP Report, 2019).

In response to the crime, Russia signed the following two treaties in 2000 and ratified both in 2004: The United Nations Convention against Transnational Organized Crime, including the Protocol on the Prevention, Suppression and Punishment of Trafficking in Persons, in particular Women and Children, also known as the Palermo Protocol, and the Protocol against Land, Sea and Air Migrant Smuggling.

In 2004, the Federal Law 162-FZ3 introduced two anti-trafficking documents, namely 127.1 (Human Trafficking) and 127.2 (Use of Forced Labour), into the Russian Criminal Code (CC). The various types of exploitations are mentioned in Article 127-1 of the Russian Federation Penal Code: abuse of the prostitution of others; other forms of sexual exploitation; forced labour (or services); servitude. In the context of Article 127-1 of the Russian Federation's Criminal Code, the concept of a person's exploitation may be defined as a systematic appropriation of the results of the labour of another person committed by deception, misuse of trust, violence or threat of violence, or exploitation of the dependent position of the injured party (Ryazantsev, 2014). Russian law does not include a description of a "victim of trafficking." (Molodikova, 2020). Rather, the Russian definition of trafficking focuses mainly on the process of trafficking and the types of exploitation; the Russian definition does not focus on force, fraud and coercion. The definition of 'human trafficking' itself was especially absent in legislation and the practice of state authorities and law enforcement agencies. Despite the lack of concerted efforts, there have been claims that some agencies have taken steps to address trafficking, including by naming some victims, although the number of victims that the government has reported remained insignificant.

Human trafficking and the use of slave labour are serious and burning issues which are currently relevant to Russia. The state structures in the Russian federation dramatically step up their activity to counteract human trafficking after signing the Palermo Protocol in 2000. In 2001 the Commission on the Status of Women attached to the Government of the Russian Federation was launched at the initiative of the Ministry of Foreign Affairs. In 2002, the Ministry of Foreign Affairs formed an internal working group to tackle violence against women and human trafficking. In 2002, the 
State Duma Committee for Civil, Criminal, Arbitration and Procedural Law formed an inter-agency working group to draft a federal bill to combat trafficking in persons. However, in reality, the state machine works poorly: there is no funding for victim protection and both victims and witnesses often don't want to testify in court, fearing revenge from their perpetrators. Not surprisingly, Russia has continued to be placed in Tier 3 since 2020 in U.S Trafficking in Persons (TIP) Report.

The state plays an important role in regulating labour migration in Tajikistan. In 2004 Tajikistan adopted a law "On combating human trafficking," and the Criminal Code contains several relevant articles, especially Article 130 (kidnapping, including through deception), Article 130(1) (human trafficking for exploitation), Article 131 (illegal confinement), Article 132 (illegal recruitment for exploitation) and Article 16 (child trafficking). These provisions generally provide for sentences of imprisonment from 5 to 8 years, or up to 20 years for serious crimes. Article 132 provides for a fine or imprisonment for up to 2 years. Several human right and social protection rights are questioned about the inhuman condition of the labour migrants. Thus thereafter in 2004; both Russian federation and Tajikistan signed a bilateral agreement on labour and social protection of Tajik citizens looking for jobs in Russia. Tajikistan accepted this agreement in January 2005, but Russia approved it only in July 2006. This agreement signifies some most important steps toward improvement in the status of Tajik migrants working in Russia (Jones et al, 2007). Tajikistan introduced a labour migration policy in 2011, covering the 2011-2015 period. In it, the state acknowledges the effect of labour migration on the economy for the first time and the need for a radically new approach to labour migration regulation in Tajikistan. The primary objective of this strategy is to establish legal and institutional frameworks for controlling migration and providing services to migrants and their communities, and to a lesser degree to provide relevant services to migrants. In July 2014, Tajikistan enacted a new law "On Combating Human Trafficking," but given the country's expansive legislative structure to control labour migration, Tajik people are among Central Asia's most under-protected labour migrants while living in Russia and Kazakhstan's recipient countries (Ryazantsev, 2016).

Besides national strategy for Tajikistan on binding policies are only initiated by the government when the incoming remittances play a significant role in the country's overall GDP growth. The government of Tajikistan adopted several measures to initiate labour migration and protection of migrant's right in the host countries. But the majority of the labour migrants staying in Russian federation are illegal. Russia amended its labour regulations on foreign workers in 2015, imposing administrative penalties and expulsion for those who do not comply with the rules of residency. Additionally, those 
who refuse to pay taxes or administrative fines during their stay in Russia are imposed under a temporary ban under re-entry, varying from 5 to 10 years. The 2016 IOM's study on 'Migrant Vulnerabilities' listed 're-entry ban migrants' as one of Tajikistan's most vulnerable groups. These migrants do not have a socio-economic status and very little work prospects in Tajikistan, rendering them more vulnerable to radicalisation, although many are also in poor health, with a rising number suffering from tuberculosis or HIV. Today, labour migration acts as a key factor in reducing poverty in Tajikistan.

\section{Increased vulnerabilities due to Covid-19}

The COVID-19 pandemic, has caused a humanitarian and financial dilemma for Central Asian migrants, with many remaining trapped in transit and destination nations. Recognizing trafficking even in normal times is difficult. The pandemic has widened the vulnerabilities of trafficking in remittances backed Tajikistan. Today, migrants account for a considerable portion of the detected trafficked victims: $65 \%$ in Western and Southern Europe, $60 \%$ in the Middle East, 55\% in East Asia and the Pacific, 50\% in Central and South-Eastern Europe, and 25\% in North America (UNODC, 2020). The migrants who are working legally can also be exploited as majority of these people are unaware of their labour rights and this is true to Tajik labour migrants.

With the pandemic, families are in terrible situations as a result of the loss of work and remittances. Many migrants are unable to pay the cost of living in the countries they have moved to due to a lack of jobs and meagre resources. Hundreds of Tajik migrants have found themselves in a similar scenario in Kazakhstan and Russian Federation, both major destination countries for the same. Air, rail, and bus services were all suspended when Russia and Kazakhstan declared a state of emergency and closed its borders to stop the spread of COVID-19. Many migrants were stranded at the border, unable to return home. They were packed together, unable to maintain social distance and hygiene increasing the risks of getting affected (USAID, 2020).

The pandemic has created new vulnerabilities with increased inflation and unemployment in the region. The government of Tajikistan has backed migration, which serves as a safety valve for the country's economy and stability. But with the effects of the pandemic and global recession, employment opportunities reduced significantly created fresh grounds for trafficking network. The impact of the crisis on household income is predominantly felt as a result of disruptions in business and business activities, as well as the resulting loss of working hours and decreases in remittances. Due to the drop in demand for services, small and medium-sized businesses (SMEs) and the self-employed became extremely vulnerable. (UNDP, 2021). Approximately 500,000 labour migrants are said to be returning home to 
Tajikistan from Russia amid the pandemic, resulting in a dramatic drop in remittance inflows. As a result, local labour markets are burdened with increased demands for positions that are frequently non-existent (OECD, 2020).

Nearly ten million Central Asian migrants were registered in Russia in 2019. The number of migrants from Tajikistan is enormous when compared to the entire number of individuals of working age in Russia, accounting for about half of all able-bodied persons in 2019 (Mogilevskii, 2020). A decline in remittances will significantly increase the vulnerability in the country. It will also be followed by the increase of illegal networks where people are now desperately looking for jobs for sustaining livelihood. Lockdowns have also increased the risk of assault, exploitation, and abuse directed at women. There has been an increase in the incidence of domestic violence all over the world where Tajikistan is no exception. When shocks occur, the high incidence of informality exposes the consequences of precarious employment. For future resilience to be integrated into the economic systems of Central Asian countries, policies and programs that combat informality, labour market inequities, contracting, and access to social protection must be rethought.

\section{Conclusion}

Human trafficking is a global humanitarian issue, yet quantitative research on the subject is scarce. Migration is a gigantic and seemingly intractable phenomenon in Tajikistan, with low income and poor literacy. With low socio-economic status, the majority of these migrants are involved in the low skilled sector in the destination countries. Economic vulnerability has always been a regulating factor for increased trafficking among the labour migrants. These migrants are often exploited and employed in hazardous work. A significant proportion is in bonded servitude and sexual entrapment that amounts to slavery, which has lifelong devastating effects. Individual trafficking risks are substantially higher in places with strong emigration flows, where majority of the Tajik migrants come from rural areas. Lower recruitment costs for traffickers in emigration areas, as well as, to a lesser extent, more negative self-selection into migration, are the reasons behind this. The findings also suggests that unlawful migration raises the likelihood of human trafficking, and that greater information, such as through public awareness campaigns, could be an effective method for reducing the crime. These findings could aid governments in focusing anti-trafficking efforts more effectively. In recipient states, national and international NGOs already play an essential role in providing support and restitution to migrant workers, particularly women workers, but social partners' role has been minimal.

Majority of the victims are not recognized as trafficked victims and end up in more exploitation both in the country of origin and destination. There 
is a significant lack of protection and prosecution efforts in the region where conviction rate for the traffickers is significantly low. Compared to the cases of human trafficking and the prosecuted cases picturizes a huge gap which needs to addressed. As a preventive measure, public awareness campaigns on the hazards and perils of irregular migration, as well as the problem of migrant trafficking and associated crimes, should be undertaken. The high corruption index also breeds the existing problem along with huge policy gaps among the nations.

As per the United Nations, Tajikistan's population will swell to 10.4 million by 2050 , including 6.6 million working-ages. It also predicts that by 2050, Russia's population will fall by 30 million, to 112 million. Greater opportunities in Russian federation and other neighboring countries will always attract these poor migrant workers from the country for a better living. Despite severe challenges faced by the Tajik labour migrants, Russia will continue to be the most preferable destination for them. Barriers created by the two economic crises in 2008 and 2014 somewhat declined the number of migrants in Russia which had a clear impact on the remittances and Tajik economy. But migration continued after a short pause. There is no alternative to migration in Tajikistan as there are no significant effort of the government to create employment opportunity in the country. Similarly with the advent of Covid-19 see a huge drop of migrants in the destination countries as lockdown started to contain the disease. The situation created by the pandemic increased fresh grounds of vulnerabilities across the world with huge unemployment and rising inflation. Severe changes in Russian immigration laws to control irregular and illegal migration has also seen a downfall in the migration movement in the country. The xenophobic feelings in Russian Federation also increased after the economic crisis which reduced Tajik migrants to a great extent. The new laws led to mass departures of illegal migrants and are banned from entering Russia for some time. But still with the stand of Russian demographic decline along with Tajik population increase, Russia will stand as a major place for labour migrants to work for.

The "migratory corridor" in the region has been staffed by migrant smuggling channels that operate both locally and internationally to smuggle migrants from their countries of origin to their final destination. This entails establishing a full infrastructure of contacts, modes of transportation, hiding places, fake papers, and logistical methods along the path, as well as finetuning the corruption processes. Faced with the growth, diversity, and complexity of this illegal mechanism, state agencies have to implement a number of preventive and criminal prosecution methods, as well as meaningful action, focusing specifically on the migratory groups discovered in their jurisdictions. Analysis groups should also be established at the interinstitutional and regional levels as a further step in establishing a more 
consistent structural, normative, and operational framework that restricts traffickers' activities in the border areas.

As for the volume and dynamics of the human trafficking among the labour migrants, the actual numbers are never reflected and recognized compared to the other forms of crime. However, increasing number of labour migrants from the country always put these migrants into a severe vulnerability to trafficking in the destination countries. The Central Asian countries along with Tajikistan have devised plans and strategies to combat the illegality of this criminal mode, and they have taken the rise of migrant smuggling as an international crime sponsored by organized crime substantially. But the need is to establish and act that are realistic, practical, and complete, and are taken in a less reactive manner.

In light of the existence of criminal activity in the smuggling and trafficking of migrants, civil servants and other civilian actors such as police and immigration officials, criminal justice operators, and officials in international cooperation must receive specialized training related to a comprehensive response to crime. The training must be focused on the investigation and prosecution of human trafficking, and it must be provided to people and organizations that are involved in the care and safety of trafficked migrants to some extent. Various government agencies, other professional bodies, community leaders and all civil society need to work together to demand labour rights and stop their exploitation and trafficking. The value of human labour appears to be systematically degraded and political rhetoric further marginalizes already disregarded migrants. The COVID-19 epidemic has also demonstrated the resiliency of remittances and migrants, highlighting the need for long-term solutions to the challenges and possibilities presented by seasonal migration movements. Governments must also consider how these erratic remittance flows might be effectively channeled toward domestic job creation and private sector expansion.

\section{References:}

1. $\mathrm{ADB}(2016)$, Tajikistan country gender assessment, Asian Development Bank, Manila, Philippines ISBN 978-92-9257-505-2.

URL: $\quad$ https://www.adb.org/documents/tajikistan-country-genderassessment-2016

2. Aronowitz. Alexis A.(2001), "Smuggling and Trafficking in Human Beings: The Phenomenon, The Markets that Drive It and the Organisations that Promote It," European Journal on Criminal Policy and Research, no.2 (2001): 164

3. Buckley, M. (2018), "The Politics of Unfree Labour in Russia", Cambridge, UK: Cambridge University Press. 
4. Chiovenda, Melissa Kerr (2013). "Tajik Labour Migration to Russia: Tajik Responses to Migrant Vulnerability and Russian State Policies" The Eurasia Studies Society Journal, Vo.2. No.1. February 2013

5. Dutta, Mondira (2016). "Understanding Maldives in the context of Human Trafficking" in Henrik Berglund, Mondira Dutta, Per Hilding(eds.) Development and Regional cooperation in Central Asia and South Asia-Euro Asian Perspectives, New Delhi: Pentagon Press.

6. FIDH(2011). "Tajikistan: Exporting the workforce - at what price? Tajik migrant workers need increased protection, Report, International Federation for Human Rights, September 2011

7. Gallagher, Anne.(2001) "Human Rights and the New UN Protocols on Trafficking and Migrant Smuggling: A Preliminary Analysis," Human Rights Quarterly 23, no.4 (2001): 1001.

8. Gromov, S.V(2006). "Criminal Law Assessment of Human Trafficking and Use of Slave Labour", Dissertation for a competition for the academic title of candidate of legal sciences, Moscow, 2006. p. $82-23$

9. Human Rights Watch(2009). "Are You Happy to Cheat Us?": Exploitation of Migrant Construction Workers in Russia. Human Rights Watch, New York. Available from www.hrw.org/sites/default/files/reports/ Russia0209web_0.pdf.

10. ILO(2006). Forced labour in the Russian federation today: Irregular migration and trafficking in human beings, International Labour Organization, International Labour Office Geneva 2006, ISBN 9221178412

11. ILO (2004). Forced Labour in Modern Russia: Unregulated Migration and Human Trafficking. - Moscow: International Labour Organization, 2004. - p. 102

12. ILO(2008). "Forced labour and human trafficking: A toolkit for trade unions in Zambia", Special Action Programme to Combat Forced Labour, International Labour Organization, 2008

13. International Labour Organization (2012). "New ILO Global Estimate of Forced Labour: 20.9 million victims", URL: ,http://www.ilo.org/global/about-the ilo/newsroom/news/WCMS_182109/lang-- en/index.htm

14. International Organization for Migration (2014). "Tajik migrants with Re-entry Bans to the Russian Federation". International Organization for Migration (IOM)2014, Dushanbe, Tajikistan

15. International Organization for Migration(2003)."Geopolitical Factors Shaping Migration in Central Asia.” URL: www.iom.int/austria/tcc/ 
16. International Organization for Migration(2006), Remittances and their impact to social life in Khtalon Oblast, Republic of Tajikistan, Analytical report, IOM Centre Sharq, IOM Dushanbe.

17. International Organization for Migration (IOM) 2009,, Economic dynamics of labour migrants' remittances in Tajikistan by Khakimovparvizsh and mahmadbekovmoenshosh, April 2009, Tajikistan

18. International Organization for Migration(2014) "Tajik Migrants with Re-entry Bans to the Russian Federation", IOM Report, 2014 Dushanbe, Tajikistan

19. International Organization for Migration(2001). Deceived Migrants from Tajikistan: A Study of Trafficking in Women and Children: International Organization for Migration, 2001, Dushanbe, Tajikistan

20. Jones, Larissa. et al.(2007), "Migration and poverty reduction in Tajikistan", Migration globalization and poverty working paper $\mathrm{c} 11$ : $1-30$

21. Kelly, Liz (2005), "Fertile fields: Trafficking in persons in Central Asia", IOM, 2005, Vienna

22. Mogilevskii, Roman(2020), "Labour Market and Technological Development in Central Asia", University of Central Asia Working Paper \#58 (2020) (Bishkek, Kyrgyz Republic: University of Central Asia

23. Mohapatra, N. K(2013). "Migration and Its Impact on Security of Central Asia", India Quarterly: A Journal of International Affairs, 69(2), 133-157. doi:10.1177/0974928413481883

24. Molodikova, Irina(2020). "One Step Forward and Two Steps Back: Migration Policy and Human Trafficking in the Russian Federation since the Palermo Protocol of 2020", Journal of Human Trafficking, 6:2, 141-155, DOI: 10.1080/23322705.2020.1690101

25. Mughal, Abdul Ghaffar(2007). "Migration, Remittances, and Living Standards in Tajikistan." A Report Based on Khatlon Remittances and Living Standards Measurement Survey KLSS 2005, Tajikistan

26. OECD (2020), "Covid-19 crisis response in Central Asia dated 16th November 2020, URL: https://www.oecd.org/coronavirus/policyresponses/covid-19-crisis-response-in-central-asia-5305f172/

27. Olimova, Saodat and Igor Bosc(2003), "Labour Migration from Tajikistan", International Organization for Migration in Cooperation with the Sharq Research Center, ISBN 92-9068-163-2, Dushanbe, Tajikistan

28. OSCE(2011). "Trafficking in human beings for the purpose of labour exploitation: a reference paper for Bosnia and Herzegovina", ISBN: 
978-92-9234-016-2, Organization for security and cooperation in Europe, July 2011, Bosnia and Herzegovina

29. Regional Central Asia conference(2006) "Combating Trafficking in Human Beings - Regional Response". Jointly organized by the OSCE and the Republic of Kazakhstan Astana, Kazakhstan 18-19 May 2006

30. Rex News, 2012 "The Life of Slaves: How Labour Migrants become Prisoners. - Statement from the Moscow Office for Human Rights on the use of migrant slave labour", the REX news agency, 26 November 2012. URL:(www.iarex.ru/articles/31509/html

31. RIA, 2018, December 21, "V MVD nazvali chislo nelegal'nykh migrantov na territorii Rossii", RIA news. URL: https://ria.ru/20181221/1548398795.html

32. Ryazantsev, S.V. and N. Horie.(2012) "Modelling labour migration flows from countries in Central Asia to Russia. Economic-sociological research”, Moscow: Nauchnyi mir, 2011. - p. 35; Migration Bridges in Eurasia: Collection of Papers and Materials of International Symposium Participants/ ed. by S.V. Ryazantsev, Associate Member of the Russian Academy of Sciences - Moscow: Ekon-inform, 2012. - p. $15-16$

33. Ryazantsev, S.V., I.D. Gorshkova, Sh.Yu. Akramov, F.Sh. Akramov.(2012) "The practice of using licences for work performed by foreign nationals who are migrant workers in the Russian Federation", Moscow: International Organisation for Migration, 2012:15

34. Ryazantsev, Sergey (2014). "Trafficking in Human Beings for Labour Exploitation and Irregular Labour Migration in the Russian Federation: Forms, Trends and Countermeasures", Report, The Council of the Baltic Sea States Secretariat, Moscow/Stockholm, April 2014

35. Ryazantsev, Sergey (2016), "Labour Migration from Central Asia to Russia in the Context of the Economic Crisis" \# 55 Valdai Papers, August 2016

36. Sarrica, F (2015). "Stealing labour: an economic analysis of forced labour and human trafficking", Forum on Crime and Society, pp 137154. doi:10.18356/9df6367a-en.

37. Ronald Skeldon(2000), "Trafficking: A Perspective from Asia," Special issue, International Migration 38, no.1 (2000): 9 https://www.stat.tj/en/

38. Stephanie, Hepburn and Rita, Simon. J.(2013) "Russia: Human Trafficking around the World: Hidden in Plain Sight" New York: Columbia UP, 2013, Columbia University Press.

39. Tajikistan Extended Migration Profile, 2010 "Tajikistan Extended Migration Profile", Report, Prague Process, 2010 Building Migration 
Partnerships (BMP) Funded by the European Union's Thematic Programme

40. United States Dept of State TIP report (2012), Trafficking in Persons Report 2012, URL: https://www.state.gov/j/tip/rls/tiprpt/2012/

41. United States Dept of State TIP report (2014), Trafficking in Persons Report 2014, URL: https://www.state.gov/j/tip/rls/tiprpt/2014/

42. United States Dept of State TIP report (2019), Trafficking in Persons Report 2019, URL: https://www.state.gov/j/tip/rls/tiprpt/2019/

43. Tyuryukanova, Elena (2005), " Forced Labour in the Russian Federation today: Irregular Migration and Trafficking in Human Beings”, ILO, Geneva, International Labour Office, 2005 ISBN 92-2117840-4 (print) ISBN 92-2-117841-2 (web pdf

44. Tyuryukanova, E.V.(2006) "Human Trafficking in the Russian Federation: Overview and Analysis of the Current Situation".Moscow: Institute for Urban Economics, 2006. - p. 58

45. Umarov.K and K.Warikoo (eds)(2015), Tajikistan in the 21st century, society politics and economy, New Delhi: Pentagon Press, ISBN 97881-8274-821-7

46. The UN/IOM Working Group on Trafficking in Human Beings (2005). Human trafficking in the Russian Federation: Inventory and analysis of the current situation and responses.

47. UNICEF(2011), "Impact of labour migration on children left behind in Tajikistan", Ref no-ssa/tada/2010-00000579-0, November 2011, Dushanbe, Tajikistan.

48. UNDP(2021), "COVID-19 and Central Asia: Socio-economic impacts and key policy considerations for recovery", United Nations Development Programme, 2021.

49. UNODC. UN.GIFT (2008), Human Trafficking: An overview, United Nations, New York, pp:1-60.

50. UNODC(2020), UNODC, Global Report on Trafficking in Persons 2020 (United Nations publication, Sales No. E.20.IV.3), Vienna, URL: https://www.unodc.org/documents/data-andanalysis/tip/2021/GLOTiP_2020_15jan_web.pdf

51. United Nations Treaty Collection, depository, New York, 15th November 2000, URL: https://treaties.un.org/pages/ViewDetails.aspx?src=TREATY\&mtdsg _no=XVIII-12-a\&chapter $=18 \&$ clang=_en

52. "Tajik Migrants Return Home" dated August 10, 2020, Accessed at https://www.usaid.gov/tajikistan/program-updates/aug-2020-tajikmigrants-return-home 
53. Vinokurov, Evgeny and Vladimir Pereboyev.(2013) "Labour migration and Human capital in Kyrgyzstan and Tajikistan: Impact of accession to SES" EDB Eurasian Integration Yearbook 2013: 68-88.

54. URL:https://www.google.com/search?q=gdp+per+capita+Tajikistan $\& o q=g d p+$ per+capita+taj\&aqs=chrome.1.69i57j017.11966j0j4\&sourc eid $=$ chrome $\&$ ie $=$ UTF-8)

55. World Bank(2015), Tajikistan slowing growth, rising uncertainties, Tajikistan Economic update No 1/spring 2015, Tajikistan

56. Zagorsky, G.I. , M.A. Kaufman, T.F. Moiseeva, N.V. Radutnaya(2009): Court Proceedings in Human Trafficking Criminal Cases. - Moscow, "Yuridicheskaya literatura", plabour p. 65 